\title{
Crude Terpenoid Influence on Mule Deer Preference for Sagebrush
}

\author{
TIMOTHY L. RERSONIUS, CARL L. WAMBOLT, JEFFREY R. STEPHENS, AND RICK G. KELSEY
}

Abstract

Samples of current year's growth of leaves and stems were collected in February 1983 from basin big sagebrush (A rtemisia tridentata Nutt. tridentata), Wyoming big sagebrush (A.t. wyomingensis Beetle and Young), mountain big sagebrush (A.t. vaseyane [Rydb.] Beetle), and black sagebrush (A. nova Nels.) on a mule deer (Odocoileus hemionus hemionus) winter range near Gardiner, Montana. Samples were from both lightly and heavily used plants (form classes) within each taxon. Crude terpenoids were separated into 3 groups: headspace vapors, volatile, and nonvolatile crude terpenoids. Compounds in each group are thought to stimulate the sensory organs of mule deer. Individual compounds were identified and quantified for comparison with preference ranks among taxa and between utilization form classes. Seven compounds were selected by discriminant analysis as indicators among the 4 taxa, with methacrolein+ethanol, $\rho$-cymene, and the sesquiterpene lactones the most probable preference determinants. Seven other compounds were found useful for separating plants within taxa into form classes. Chemical differences between the 2 form classes, however, were less distinguishable than were those among the 4 taxa.

Key Words: Artemisia tridentata, Artemisia nova, Odocoileus hemionus hemionus, forage selection, terpenoids

Knowledge of the motivation behind forage selection by ungulates is vital to predicting and manipulating range forage/herbivore interactions. Given the opportunity to select, mule deer (Odocoileus hemionus hemionus) will preferentially browse certain species of sagebrush over others (Hanks et al. 1971, Scholl et al. 1977, Sheehy and Winward 1981, Welch et al. 1981, 1983). Even within a taxon there is differential utilization (Welch et al. 1981, 1983, Behan and Welch 1985). Factors influencing the interactions among plants and herbivores are numerous and frequently complex, but there is substantial evidence that the secondary metabolic products synthesized by a plant can function as mediating agents (Rosenthal and Janzen 1979). Sagebrush species synthesize and store relatively large quantities of terpenoids on their epidermal surface in glandular trichomes (Kelsey and Shafizadeh 1980, Kelsey et al. 1982, Kelsey 1986). Many of the compounds that have been identified in sagebrush species are also known to exhibit a variety of biological activities (Tatken and Lewis 1983, Kelsey et al. 1985). Previous studies relating sagebrush chemistry to mule deer preference have focused on the monoterpene composition and concentrations (Scholl et al. 1977, Welch et al. 1983, Behan and Welch 1985). No significant relationships were found between the monoterpenes and utilization. The monoterpenes represent only a portion of the compounds of sagebrush foliage, however, and other constituents could be involved. This study was undertaken to identify epidermal compounds associated with differences in sagebrush preference by mule deer.

\section{Materials and Methods}

\section{Site Description}

The study site was a mule deer winter range near Gardiner,

Authors are former research assistant and associate professor, Animal and Range Sciences Department, Montana State University, Bozeman 59717; and former research assistant and research associate professor, Department of Chemistry, University of Montana, Missoula 59812.

Research was funded by the Montana Agricultural Experiment Station (J-1786) and by National Science Foundation Grant No. PCM-8112585.

Manuscript accepted 5 June 1986.
Montana, immediately north of Yellowstone National Park. Elevation of the rolling bench at the base of the Absaroka Mountains is $1,950 \mathrm{~m}$. Precipitation averaged about $400 \mathrm{~mm}$ during the period 1941 to 1970 (USDA 1981), with about half of this moisture as snow. The area was dominated by basin big sagebrush (Artemisia tridentata Nutt. tridentata), Wyoming big sagebrush (A.t. wyomingensis Beetle and Young), mountain big sagebrush (A.t. vaseyana [Rydb.] Beetle), and black sagebrush ( $A$. nova Nels). Sampling was restricted to plants from a "natural cafeteria", an area of $30 \times 60 \mathrm{~m}$, where the 4 taxa occurred intermixed in nearly equal biomasses. This natural cafeteria was a mosaic of distinct microsites controlled by slope angles, soil properties, and exposure, that in turn resulted in a plant community dominated by a combination of sagebrush taxa not ordinarily found together. Because the natural cafeteria was small, contained nearly equal quantities of each taxon, and had no physical limitatiens to deer access, utilization within the area should have reflected mule deer preference. Bluebunch wheatgrass (Agropyron spicatum [Pursh.] Scribn.) and Idaho fescue (Festuca idahoensis Elmer) were important subdominants. Mule deer were consistently observed on the cafeteria browsing sagebrush from late November into April.

\section{Sagebrush Utilization}

To document differential utilization on the 4 sagebrush taxa, 1,136 available vegetative leaders were tagged on 124 plants evenly distributed throughout the cafeteria. Tags were installed prior to the 1982-1983 period of winter deer use. Tagged leaders were re-examined after winter browsing to determine the percentage of total leaders browsed. It was not practical to measure length of leader removed as most plants exhibited a browsing history in the form of very irregular and twisted leader growth that could not be measured and pre- and post-browsing accurately.

\section{Sample Collection}

In early February, 10 plants were subjectively selected and sampled in each taxon, 5 representing the light-use form class (open, growthy, relatively unbranched crowns), and 5 representing the heavy-use form class (dense, intricately branched crowns, clublike appearance). Form classes can be viewed as indicators of historic preference for individual sagebrush plants (Cook and Stoddart 1960, McNeal 1984, Kelsey 1986). It is not implied that individual plants from different taxa that exhibit the same form class have historically received the same amount of actual use. Instead, it is likely the response is partially under genetic control and will therefore vary among sagebrush taxa. A sample consisted of 15 of current year's leaves and stems which closely approximated the actual tissue consumed by mule deer. Plant samples were sealed in individual air-tight plastic bags, double bagged, placed on dry ice, and transported to a freezer for storage at $-20^{\circ} \mathrm{C}$ until chemically analyzed.

\section{Crude Terpenoid Isolation}

Seven to 8 grams of frozen leaf and stem tissue from each sample were brought to room temperature in a sealed plastic bag. The plant material was transferred to a beaker, covered with chloroform $(24 \mathrm{ml} / \mathrm{g})$ and stirred gently for $5 \mathrm{~min}$. The extract was filtered through sharkskin paper into a preweighed flask for concentration and weighing as described by Kelsey (1986). Extracted tissue, including nonglandular trichomes that had dislodged from the 
leaves and collected in the filter paper, was dried at $100^{\circ} \mathrm{C}$ overnight, cooled to room temperature in a desiccator, and reweighed. Crude terpenoid concentrations were calculated as percentage of extracted tissue dry weight.

The most volatile compounds are lost from the extract during concentration, whereas a portion of the less volatile monoterpenes, remain in the final residue. The latter can be separated from the nonvolatile lactones and waxes by steam distillation (Kelsey et al. 1982). After redissolving the concentrated extract in chloroform, steam was bubbled through the solution for 10 minutes. Volatile compounds were captured in a cold water $\left(10^{\circ} \mathrm{C}\right)$ condenser and collected in a flask with chloroform and water. Nonvolatile components remained in the distillation flask with condensed water. The resulting volatile and nonvolatile crude terpenoid fractions were concentrated, and weighed, like the initial extract above (Kelsey 1986).

\section{Volatile Crude Terpenoid Analysis}

Composition of the volatile crude terpenoid fraction was analyzed by gas-liquid chromatography (GLC). A $0.1 \mu$ l sample of extract was injected onto a $4-\mathrm{m} \times 3-\mathrm{mm}$ stainless steel column packed with $10 \%$ Carbowax (TPA) on 80/100 to 100/120-mesh Gas Chrom Q, in a chromatograph with a flame ionization detector and nitrogen carrier gas. Column temperature was programmed for $50-200^{\circ} \mathrm{C}$, with a $10^{\circ} / \mathrm{min}$ rise and final temperature hold ( $5 \mathrm{~min}$ for headspace samples, and $15 \mathrm{~min}$ for volatile oils). Chromatograms were printed by a Hewlett Packard 3380 A integrator recorder. Integrater conversion factors for quantifying individual oil components were determined by injecting known quantities of methacrolein as a reference for highly volatile compounds and camphor as a reference for the less volatile monoterpenes. Concentrations were standardized for differences in initial sample size and expressed as percentage of extracted tissue dry weight.

Compounds were identified by comparison of retention times to known references, and by GLC/mass spectrometry. For this analysis, approximately $0.05-0.1 \mu \mathrm{l}$ of the volatile crude terpenoid oil (neat) was injected onto the GLC column (4-m $\times 3-\mathrm{mm}$ stainless steel, $10 \%$ Carbowax on $80 / 100$ CWHP, He carrier gas) with a programmed temperature of $50-200^{\circ} \mathrm{C}$ at $10^{\circ} / \mathrm{min}$. Mass spectra of the oil components were identified by comparison with known reference samples and published spectra (Stenhagen et al. 1974, Epstein et al. 1976).

\section{Sesquiterpene Lactone Analysis}

Analysis of the nonvolatile crude terpenoid fraction centered on isolation, quantification, and identification of sesquiterpene lactones, 1 of the major classes of compounds in this fraction that could influence preference. Other constituents present but not studied included cuticular waxes, some flavonoids, and possibly other unknown compounds.

The concentrated nonvolatile crude terpenoid fractions from each plant sample were dissolved in chloroform, or a mixture of chloroform and ethanol, and diluted to $25.0 \mathrm{ml}$ with the same solvent. A measured volume (between 2 and $6 \mu \mathrm{l}$ ) was injected onto a $1.8-\mathrm{m} \times 3-\mathrm{mm}$ stainless steel column packed with $3 \% \mathrm{OV}-17$ on 100-120 mesh Gas Chrom Q. Oven temperature was set isothermally at $205^{\circ} \mathrm{C}$. The sesquiterpene lactone matricarin $(5 \mathrm{mg} / \mathrm{ml})$ was used as a reference. Microliter quantities of the diluted extracts were analyzed by thin-layer chromatography (TLC) (Kelsey et al. 1976). TLC and GLC analyses indicated a similar chemical composition for plants of the same species. Therefore, measured aliquots were taken from each extract and combined by taxa to isolate and identify specific sesquiterpene lactones. Compounds were separated and purified by preparative TLC, and then compared with reference samples using TLC, GLC, and infrared (IR) spectroscopy.

Total sesquiterpene lactone concentration in each of the 40 extracts was measured by comparing the integrated area of the lactone moiety absorbence band with that of a reference compound at known concentrations, using a Nicolet model MX-1 Fourier Transform Infrared Spectrometer with liquid sample cells.
Deacetylmatricarin, deacetoxymatricarin, and cumambrin $B$ were used as references for basin big sagebrush, mountain big sagebrush, and black sagebrush, respectively. No reference was needed for the extracts of Wyoming big sagebrush because they had no measurable lactone absorbence; there were either no sesquiterpene lacetones present, or only very low concentrations, below the detection limits of the technique.

\section{Headspace Analysis}

Sagebrush produces some very volatile compounds that are lost during the rigorous distillation, evaporation, and drying procedures used in the crude terpenoid isolation process. These compounds are likely to escape from the plant into the atmosphere. Mule deer may be able to detect them by smell without having to sample the foliage. These very volatile components were analyzed as headspace vapors using a modification of the procedure reported by Kelsey et al. (1983). Approximately $1 \mathrm{~g}$ of frozen whole tissue was sealed in a $60-\mathrm{ml}$ vial fitted with an air-tight rubber septum. The sample was then adjusted to room temperature and placed in an oven at $60^{\circ} \mathrm{C}$ for $15 \mathrm{~min}$. An air-tight syringe, with a valve for sealing the contents was used to extract $1.0 \mathrm{ml}$ of vapor from the vial. After closing the valve, the vapor was compressed to $0.1 \mathrm{ml}$ (as recommended by the syringe manufacturers), and injected into a column in a GLC as described for the volatile crude terpenoid fraction. The tissue sample was then removed from the vial, dried overnight at $100^{\circ} \mathrm{C}$, cooled to room temperature in a disiccator, and weighed. Integrator counts for individual compounds were converted to micrograms after injecting known quantities of camphor and methacrolein as references. All concentrations were standardized to compensate for differences in tissue dry weights. Compounds were identified as described for the volatile crude terpenoids.

\section{Statistical Analysis}

The data set consisted of 40 plant samples grouped into 4 taxa of 10 samples each, and 2 form classes of 5 samples within each taxon, with a quantified list of individual compounds for each sample. Stepwise multiple discriminant analysis (Nie et al. 1975) was used to identify those compounds which, when considered together and on a sample-by-sample basis, could be used to separate taxa or form-class groups on a chemical basis. Only individual compounds were entered in the analysis.

A one-way analysis of variance (AOV) was used for comparison of means among taxa. Tukey's Honestly Significant Difference (HSD) multiple range test was used to separate significantly different means $(\alpha=0.05)$. A simple t-test $(\alpha=0.10)$ was used to compare group means between the 2 form classes within a taxon.

\section{Results and Discussion}

\section{Utilization and Preference}

Mountain big sagebrush was by far the most preferred taxon, Wyoming and basin big sagebrush were intermediate, and black sagebrush was the least preferred (Table 1). This order of ranking is the same as for mule deer in Oregon (Sheehy and Winward 1981), and very similar to mule deer preference observed on a uniform garden in Utah (Welch et al. 1981, 1983).

\section{Chemical Constituents}

Many glandular terpenoids exhibit a variety of biological activities (Tatken and Lewis 1983, Kelsey et al. 1985), and their compartmentalization in trichomes allows a relatively high concentration to be maintained where they are most accessible to the sensory organs of herbivores. The complex mixture of compounds can help maximize protection against a variety of herbivorous organisms and their different sensory mechanisms. Mule deer probably depend on both olfactory and gustatory senses for monitoring forage. In our study the chemical analysis was designed to isolate groups of compounds whose individual constituents are likely to be detected by a certain sensory organ. The headspace analysis was used to identify the highly volatile compounds in sagebrush most 
Table 1. Percentage of leaders browsed during winter (1982-1983) on 4 sagebrush taxn in the natural cafeteria.

\begin{tabular}{lcc}
\hline \hline \multicolumn{1}{c}{ Number of } \\
Taxon & $\begin{array}{c}\text { leaders tagged } \\
\text { Percentage used }\end{array}$ \\
\hline mountain big sagebrush & 316 & 52 \\
Wyoming big sagebrush & 328 & 24 \\
basin big sagebrush & 254 & 19 \\
black sagebrush & 238 & 8 \\
\hline
\end{tabular}

easily detected by smell before eating or immediately after the first bite. The volatile compounds, isolated by steam distillation, were not completely evaporated during the extraction procedure, suggesting they might be detected by both the gustatory and the olfactory senses of mule deer when released by mastication. The nonvolatile crude terpenoid fraction was left with the sesquiterpene lactones, waxes, and other unidentified compounds that are detectable mainly by taste (Burnett et al. 1977).

Eighteen componds were quantified in the headspace vapors, of which 15 were identified (Table 2). Methacrolein and ethanol could not be consistently separated and were considered as one. In the

Table 2. Mean concentrations of individual compounds in the headspace vapor and volatile crude terpenoid fractions from the 4 taxa of sagebrush. Compounds listed in order of increasing retention time.

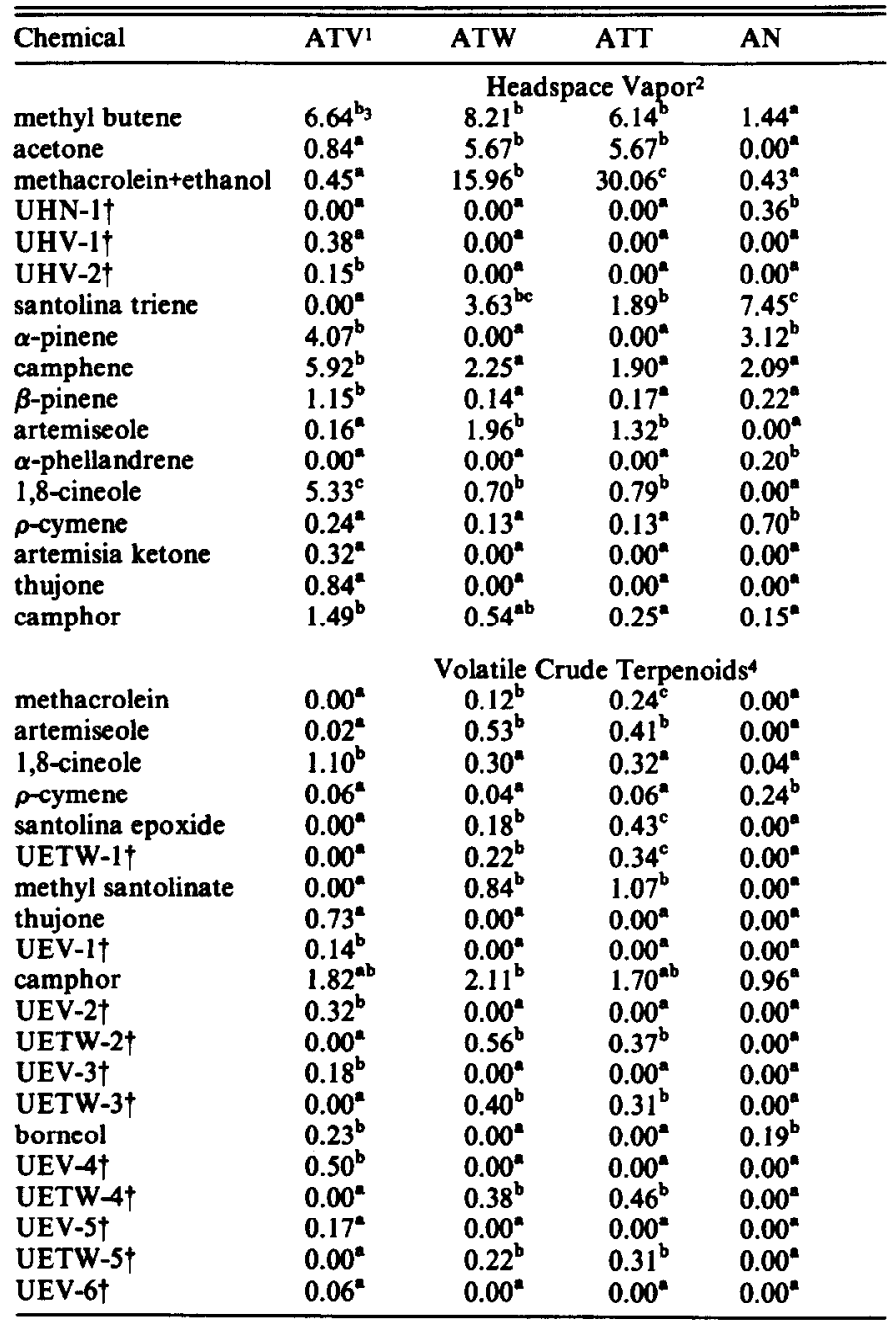

ATV: A.t. vaseyana; ATW; A. t. wyomingensis; ATT: A.t. tridentata; AN: $A$. nova. $2 \mu \mathrm{g} /$ gram of dry tissue

'Individual compounds followed by the same letter were not significantly different $(P<0.05)$ among taxa using Tukey's HSD multiple range test.

Percentage extracted-tissue dry weight.

$\dagger$ Unidentified compounds. samples that were separable, however, methacrolein constituted $80-90 \%$ of the total. Twenty compounds were quantified in the volatile crude terpenoid fractions, and 9 were identified (Table 2). Only 6 of the 32 compounds (Table 2) were common to both of these fractions. In general, the means of nearly every headspace and volatile crude terpenoid compound differed significantly $(P<0.05$ ) between at least 2 taxa (Table 2 ). In contrast, the means of only 11 of these individual compounds differed $(P<0.1)$ between the 2 form classes of any taxon (Table 3 ).

Table 3. Mean concentrations of individual compounds in the headspace vapor and volatile crude terpenoid fractions that differed significantly $(P<0.1)$ between the 2 form classes of each taxon.

\begin{tabular}{|c|c|c|c|c|c|}
\hline \multirow[b]{2}{*}{ Taxon ${ }^{1}$} & \multirow[b]{2}{*}{ Compound ${ }^{2}$} & \multirow[b]{2}{*}{ Source ${ }^{3}$} & \multicolumn{2}{|c|}{ Form Class ${ }^{4}$} & \multirow[b]{2}{*}{ P-value } \\
\hline & & & Light-use & Heavy-use & \\
\hline \multirow[t]{10}{*}{ ATV } & acetone & HD & 1.67 & 0.00 & .01 \\
\hline & UHV-2† & HD & 0.31 & 0.00 & .01 \\
\hline & camphene & HD & 2.62 & 9.22 & .04 \\
\hline & camphor & HD & 0.40 & 2.58 & .05 \\
\hline & UEV-1† & ES & 0.27 & 0.01 & .05 \\
\hline & camphor & ES & 0.84 & 2.79 & .02 \\
\hline & UEV-2† & ES & 0.43 & 0.20 & .08 \\
\hline & UEV $-4 \dagger$ & ES & 0.98 & 0.01 & .04 \\
\hline & UEV-5† & ES & 0.33 & 0.00 & .06 \\
\hline & UEV-6† & ES & 0.12 & 0.00 & .07 \\
\hline \multirow[t]{3}{*}{ ATW } & camphene & HD & 3.20 & 1.30 & .07 \\
\hline & $\beta$-pinene & HD & 0.20 & 0.09 & .05 \\
\hline & UETW-2† & ES & 0.35 & 0.77 & .09 \\
\hline \multirow[t]{2}{*}{ ATT } & acetone & HD & 4.57 & 6.76 & .07 \\
\hline & camphene & HD & 1.39 & 2.41 & .06 \\
\hline AN & - none significant -- & & & & \\
\hline
\end{tabular}

IATV: A.t. vaseyana; ATW: A.t. wyomingensis: ATT: A.t. tridentata; AN: A nova. 2 Borneol $\rho$-cymene, and UEV-3 concentrations were not significantly different between form classes, but were selected by stepwise multiple discriminant analysis as helpful for distinguishing form classes.

${ }^{3} \mathrm{HD}=$ headspace; $\mathrm{ES}=$ volatile crude terpenoids.

${ }^{4} \mathrm{HD}: \mathrm{g}$ /gram dry tissue; ES: percentage extracted-tissue dry weight. $\uparrow$ Unidentified compounds.

The total lactone concentration was measured in the nonvolatile crude terpenoid fractions (Table 4). Black sagebrush had the highest average concentration, containing 2 major components, cumambrin $A$ and $B$, and several unknowns. Wyoming big sagebrush had the lowest lactone concentration, and no individual compounds were identified. Basin big sagebrush and mountain big sagebrush both had significant quantities of lactones but differed in the chemical complexity of their respective fractions. Matricarin, deacetylmatricarin, and deacetoxymatricarin were the dominant sesquiterpene lactones in basin big sagebrush. All 3 have been previously isolated or detected in this taxa (Irwin 1971, Kelsey and Shafizadeh 1979). Mountain big sagebrush lactones were a mixture of many unidentifiable compounds, without a major constituent.

Chemical analysis of individual plants is important because of plant-to-plant variability (Kelsey et al. 1983, and observations in this study). Occasionally, a compound is present in high concentra-

Table 4. Mean concentrations' of chemical groups in the 4 sagebrush taxa.

\begin{tabular}{lcccc}
\hline \hline Fraction & ATV $^{2}$ & ATW & ATT & AN \\
\hline total crude terpenoids & $19.58^{\mathrm{as}}$ & $22.36^{\mathrm{ab}}$ & $24.59^{\mathrm{b}}$ & $21.94^{\mathrm{ab}}$ \\
volatile crude terpenoid & $5.71^{\mathrm{b}}$ & $6.81^{\mathrm{be}}$ & $7.61^{\mathrm{c}}$ & $1.82^{\mathrm{a}}$ \\
$\quad$ fraction & & & & \\
nonvolatile crude terpenoid & $13.87^{\mathrm{a}}$ & $15.55^{\mathrm{ab}}$ & $16.98^{\mathrm{b}}$ & $20.12^{\mathrm{c}}$ \\
$\quad$ fraction & $28.84^{\mathrm{ab}}$ & $39.94^{\mathrm{bc}}$ & $49.25^{\mathrm{c}}$ & $16.44^{\mathrm{a}}$ \\
headspace vapors & $2.58^{\mathrm{bc}}$ & $0.10^{\mathrm{a}}$ & $2.37^{\mathrm{b}}$ & $3.05^{\mathrm{c}}$ \\
\hline
\end{tabular}

'Headspace: $\mu \mathrm{g} / \mathrm{gram}$ dry tissue. All others are percentage extracted-tissue dry weighı.

${ }^{2}$ ATV: A.t. vaseyana; ATW: A.t. wyomingensis; ATT: A.t. tridentata; AN: A. nova. ${ }^{3}$ Means followed by the sample letter were not significantly different $(P<0.05)$ among taxa using Tukey's HSD multiple range test. 
tions in 1 sample but nearly absent in another. Compounds that occur less frequently, but in high concentrations could be overrated as preference indicators if the tissue samples were composited prior to analysis.

\section{Discriminant Analysis}

All samples were correctly placed into their respective taxa using 7 compounds identified by discriminate analysis: UETW-4, lactones, 1,8-cineole (volatile), methacrolein (headspace), methyl butene, $\rho$-cymene (volatile), and santolina triene (Tables 2 and 4 ). Mean concentrations (Tables 2 and 4 ) of all these compounds differed significantly between at least 2 taxa.

All 10 samples were assigned the correct form class for mountain big sagebrush, using 5 compounds: acetone, borneol, $\rho$-cymene, UEV-3, and UEV-2 (Table 3). Eight of 10, and 9 of 10 samples were assigned the correct form class for Wyoming and basin big sagebrush respectively, using only 1 compound each: $\beta$-pinene (Wyoming big sagebrush) and camphene (basin big sagebrush) (Table 3 ). Black sagebrush samples could not be assigned to form classes using chemical criteria.

\section{Chemical Determinants of Preference}

Compounds identified by discriminant analysis are indicators of relative preference among and within the 4 sagebrush taxa. For them to actually influence or determine preference, however, they must elicit a positive or negative herbivore feeding response. They must occur in sensibly different quantities among forage choices, and should relate in some way to the observed preferences for different forages.

Of the 7 compounds identified for distinguishing among taxa, methacrolein+ethanol, $\rho$-cymene, and the lactones are the most probable preference determinants. Methacrolein+ethanol was the largest single constituents of the headspace fraction and correlated negatively and consistently with preference for the 3 big sagebrush taxa (Tables 1 and 2). Both constituents are known irritants, particularly the methacrolein (Tatken and Lewis 1983). Black sagebrush, the least preferred taxon, had the lowest amounts of methacrolein+ethanol, but significantly ( 4 times) greater quantitites of $\rho$-cymene (another irritant) than any other taxon.

The sesquiterpene lactones may be preference determinants even though their chemical compositions were different for each taxa. Sesquiterpene lactones are bitter tasting and negatively influence white-tailed deer (Odocoileus virginianus) and eastern cottontail rabbit (Sylvilagus floridanus) preference for Veronia species (Burnett et al. 1977). Consequently, those in sagebrush must be suspected. The matricarins and cumambrins could be deterrents since they occurred in high concentrations in the 2 least preferred taxa. The cumambrins caused contact dermatitis on some human patients, while the matricarins did not (Mitchell and Dupuis 1971). Mountain big sagebrush had lactone concentrations similar to basin big sagebrush, but without any major components. This may weaken deterrent effectiveness. Although Wyoming big sagebrush was lactone-free, this does not rule out the possibility of other preference determining compounds. Artemisia pygmaea and $\boldsymbol{A}$. longiloba have no lactones, but they do contain sesquiterpene alcohols (Irwin and Geissman 1973, Shafizadeh and Bhadane 1973, Kelsey and Shafizadeh 1979). If sesquiterpene lactones influence mule deer preference, than our data indicate both total concentration and composition must be considered. The potential involvement of UETW-4, 1,8-cineole, methyl butene, and santolina triene in determining preference is less clear, as they either had a positive correlation to preference, no known biological activity, or remain unidentified.

Discriminant analysis may overlook, or ignore, some compounds if their significance among groups is limited to only a few cases. For instance, $\alpha$-phellandrene (Table 2), an irritant (Tatken and Lewis 1983), only occurs in black sagebrush (the least preferred taxon) and may be influencing preference for that species, but it was not identified as such in the discriminant function. This appears to be the only obvious omission from the discriminant list.
Compounds identified as preference indicators among taxa came from all 3 major groups of crude terpenoids (Table 4). Excluding the sesquiterpene lactones, the concentrations of all chemical groups were negatively correlated with the mule deer preference for big sagebrush subspecies (Tables 1 and 4). Mountain big sagebrush, the most preferred, had the lowest concentrations and basin big sagebrush, the least preferred, had the highest concentrations. The nonvolatile crude terpenoid fraction, detectable by taste only, was the only group of compounds whose quantity had a negative correlation with preference across all 4 taxa. Although the headspace chemicals might be detected by smell without sampling the plant, mastication of the tissue would release all constituents, providing the opportunity for simultaneous stimulation of both sense organs and allowing for synergistic interactions among all epidermal compounds.

Compounds selected to distinguish form classes were nearly all different from those that distinguished the 4 taxa. Camphor occurred in significantly higher concentrations in the heavy-use form class of mountain big sagebrush (Table 3), suggesting that it might be an attractant. It was not selected in the discriminant analysis, however, probably because of the large variation between samples and overlapping ranges of concentrations between form classes. Selecting compounds that are likely determinants of preference for the form classes was not possible.

Determining the importance of sagebrush epidermal chemicals as mediators of herbivory requires further investigation. There are numerous variables. Little information is available on chemical potencies and threshold levels for individual compounds. Carefully controlled feeding trials are necessary to clearly evaluate the effects of specific sagebrush chemicals on the feeding behavior of mule deer and other herbivores.

\section{Literature Cited}

Behan, B., and B.L. Welch. 1985. Black sagebrush: Mule deer winter preference and monoterpenoid content. J. Range Manage. 38:278-280.

Burnett, W.C., S.B. Jones, and T.J. Mabry. 1977. Evolutionary implications of sesquiterpene lactones in Vernonia (Compositae) and mammalian herbivores. Taxon. 26:203-207.

Cook, C.W., and L.A. Stoddart. 1960. Physiological responses of big sagebrush to different types of herbage removal. J. Range Manage. 13:14-16.

Epstein, W.W., L.R. MeGee, C.D. Poulter, and L.L. Marsh. 1976. Mass spectral data for gas chromatograph-mass spectral identification of some irregular monoterpenes. J. Chem. Eng. Data 21:500-502.

Hanks, D.L., J.R. Brunner, D.R. Christensen, and A.P. Plummer. 1971. Paper chromatography for determining palatability differences in various strains of big sagebrush. USDA, For. Serv. Res. Pap. INT-101.

Irwin, M.A. 1971. Sesquiterpene lactones of Artemisia. Ph.D. Thesis, Univ. California, Loas Angeles. Univ. Microfilms. Ann Arbor, Mich. (Diss, Abstr. 32B:829-B).

Irwin, M.A., and T.A. Geissman. 1973. Sesquiterpene alcohols from Artemisia pygmaea. Phytochem. 12:849-852.

Kelsey, R.G. 1986. Foliage biomass and crude terpenoid productivity of big sagebrush (Artemisia tridenta), p. 375-388. In: Proc.-Symposium on the Biology of Artemisia and Chrysothamnus. USDA, For. Serv. Gen. Tech. Rep. INT-200, Ogden, Utah.

Kelsey, R.G., M.S. Morris, and F. Shafizadeh. 1976. The use of sesquiterpene (section Tridentatae) in Montana. J. Range Manage. 29:502-505.

Kelsey, R.G., G.W. Reynolds, and E. Rodriguez. 1985. The chemistry of biologically active constituents secreted and stored in plant glandular trichomes, p. 187-241. In: E. Rodriguez, P.L. Healey, and I. Mehta (eds.), Biology and chemistry of plant trichomes. Plenum Press, New York.

Kelsey, R.G., and F. Shafizadeh. 1979. Sesquiterpene lactones and systematics of the genus Artemisia. Phytochem. 18:1591-1611.

Kelsey, R.G., and F. Shafieadeh. 1980. Glandular trichomes and sesquiterpene lactones of Artemisia nova (Asteraceae). Biochem. Syst. Ecol. 8:371-377.

Kelsey, R.G., J.R. Stephens, and F. Shafizadeh. 1982. The chemical constituents of sagebrush foliage and their isolation. J. Range Manage. 35:617-622. 
Kelsey, R.G., W.E. Wright, F. Sneva, A. Winward, and C. Britton. 1983. The concentration and composition of big sagebrush essential oils from Oregon. Biochem. Syst. Ecol. 11:353-360.

McNeal, A.F. 1984. Site characteristics and effect on elk and mule deer use of the Gardiner winter range, Montana. M.S. Thesis. Montana State Univ. Bozeman.

Mitchell, J.C., and G. Dupuis. 1971. Allergic contact dermatitis from sesquiterpenoids of the Compositae family of plants. Brit. J. Derm. 84:139-150.

Nie, N.H., C.H. Hull, J.G. Jenkins, K. Steinbrenner, and D.H. Bent. 1975. SPSS: statistical package for the social sciences. McGraw-Hill, New York.

Rosenthal, G.A., and D.H. Janzen. (Eds.). 1979. Herbivores: their interaction with secondary plant metabolites. Academic Press, new York.

Scholl, J.P., R.G. Kelsey, and F. Shafizadeh. 1977. Involvement of volatile compounds of Artemisia in browse preference by mule deer. Biochem. Syst. Ecol. 5:291-295.

Shafizadeh, F., and N.R. Bhadane. 1973. Longilobol, a new sesquiterpene triol from Artemisia longiloba (Osterhout) Beetle. Tetrahedron Lett. 24:2171-2174.
Sheehy, D.P., and A.H. Winward. 1981. Relative palatability of 7 Artemisia taxa to mule deer and sheep. J. Range Manage. 34:397-399.

Stenhagen, E., S. Abrahamsson, and F.W. McLafierty. 1974. Registry of mass spectral data. Vols. 1 and 4, John Wiley, New York.

Tatken, R.L., and R.J. Lewis, Sr. 1983. Registry of toxic effects of chemical substances (1981-82 ed.). Vols. 1, 2 and 3, U.S. Dep. HHS Publication No. 83-107. Wash. D.C.

USDA. 1981. Average annual precipitation, Montana. Soil Conservation Service, Bozeman, MT.

Welch, B.L., E.D. McArthur, and J.N Davis. 1981. Differential preference of wintering mule deer for accessions of big sagebrush and for black sagebrush. J. Range Manage. 34:409-41 I.

Welch, B.L., E.D. McArthur, and J.N. Davis. 1983. Mule deer preference and monoterpenoids (essential oils). J. Range Manage. 36:485-487.

Welch, B.L., and J.C. Pederson. 1981. In vitro digestibility among accessions of big sagebrush by wild mule deer and its relationship to monoterpenoid content. J. Range Manage. 34:497-500. 